\title{
Risk of large-scale fires in boreal forests of Finland under changing climate
}

\author{
I. Lehtonen ${ }^{1}$, A. Venäläinen ${ }^{1}$, M. Kämäräinen ${ }^{1}$, H. Peltola ${ }^{2}$, and H. Gregow ${ }^{1}$ \\ ${ }^{1}$ Finnish Meteorological Institute, Helsinki, Finland \\ ${ }^{2}$ University of Eastern Finland, School of Forest Sciences, Joensuu, Finland \\ Correspondence to: I. Lehtonen (ilari.lehtonen@ fmi.fi)
}

Received: 20 July 2015 - Published in Nat. Hazards Earth Syst. Sci. Discuss.: 14 August 2015

Revised: 2 December 2015 - Accepted: 5 January 2016 - Published: 21 January 2016

\begin{abstract}
The target of this work was to assess the impact of projected climate change on forest-fire activity in Finland with special emphasis on large-scale fires. In addition, we were particularly interested to examine the intermodel variability of the projected change of fire danger. For this purpose, we utilized fire statistics covering the period 1996-2014 and consisting of almost 20000 forest fires, as well as daily meteorological data from five global climate models under representative concentration pathway RCP4.5 and RCP8.5 scenarios. The model data were statistically downscaled onto a high-resolution grid using the quantilemapping method before performing the analysis. In examining the relationship between weather and fire danger, we applied the Canadian fire weather index (FWI) system. Our results suggest that the number of large forest fires may double or even triple during the present century. This would increase the risk that some of the fires could develop into real conflagrations which have become almost extinct in Finland due to active and efficient fire suppression. However, the results reveal substantial inter-model variability in the rate of the projected increase of forest-fire danger, emphasizing the large uncertainty related to the climate change signal in fire activity. We moreover showed that the majority of large fires in Finland occur within a relatively short period in May and June due to human activities and that FWI correlates poorer with the fire activity during this time of year than later in summer when lightning is a more important cause of fires.
\end{abstract}

\section{Introduction}

Fire is one of the major natural disturbances affecting forest dynamics and biodiversity in boreal conditions (e.g. Granström, 2001; Kuuluvainen, 2002). Globally, over 10 million hectares of boreal forest burns during a typical year; mostly in Siberia, Canada, and Alaska (Flannigan et al., 2009). A small number of large-scale fires are responsible for a large part of the burned area. For example, in Canada, fires larger than 200 ha represent $3 \%$ of the total number of fires but account for $97 \%$ of the total area burned (Stocks et al., 2002). Since small fires are much easier to control than large fires, it is essential for fire management agencies to try to suppress forest fires before they escalate to large fires that pose a risk for devastating-scale conflagrations.

In Finland, suppression of forest fires has been effective during the recent decades. Although roughly about 1000 forest fires occur annually in Finland, the average size of fires is less than 1 hectare. Fire survey flights contribute to the early detection of ignited fires and the dense forest road network in Finland aids fire fighters to reach and suppress the fires. During the nineteenth century and early twentieth century, large forest fires were still not uncommon in Finland. Back then, the average size of forest fires was over 50 ha in many years and, for instance, in 1868, over 60000 ha of state-owned forest was burned within a single year (Saari, 1923; Osara, 1949). The steep decline in forest fires across Fennoscandia in the late nineteenth century has been attributed to the cultural transition to modern agriculture and forestry (Wallenius, 2011). At the same time, no significant change in the climatological fire proneness of Finnish forests has been observed (Mäkelä et al., 2012), illustrating that the possibil- 
ity of conflagrations under the current climatological conditions still exists. This was recently demonstrated in 2014, when a single fire in Västmanland in central Sweden burned 15000 ha of forest in climatological and environmental conditions similar to Finland.

In determining the risk of forest fires, weather and climate play a key role, along with the fuel amount. High temperatures accompanied by low relative humidity and strong winds enhance the evaporation and drying of the soil and continue to make forest fuels easily flammable. Natural sources, i.e. lightning strikes, ignite less than $15 \%$ of all forest fires in Finland (Larjavaara et al., 2005), and although human activities are responsible for most forest fires, weather makes the conditions favourable for the occurrence and spreading of fires. Studies of historical fire records (e.g. Power et al., 2008; Olsson et al., 2010) have moreover linked changes in fire activity to climatic variations before any human impact was present, illustrating the crucial role of climate on fire activity. Furthermore, increased large fire activity in Canada and Alaska during the late twentieth century has been attributed to increased drought in the area (Xiao and Zhuang, 2007).

In response to global warming, the forest-fire danger is generally projected to increase in the circumboreal region, which may hamper the effectiveness of fire management (e.g. Flannigan et al., 2009). Recent studies have indicated that the forest-fire danger will also most likely increase in Finland due to global warming (Kilpeläinen et al., 2010; Lehtonen et al., 2014b; H. M. Mäkelä et al., 2014), as well as in neighbouring Russia (Sherstyukov and Sherstyukov, 2014); whereas Yang et al. (2015) concluded that northern Sweden will have a lower risk of forest fire in the future. These studies were based either on multi-model mean response (Kilpeläinen et al., 2010; Lehtonen et al., 2014b; Sherstyukov and Sherstyukov, 2014) or basically only on one climate model (H. M. Mäkelä et al., 2014; Yang et al., 2015). Moreover, only Yang et al. (2015) used simulated climate data on a daily timescale, making it possible to take predicted changes in climate variability into account when assessing the changes in forest-fire danger.

To complement the above-mentioned studies, we estimate the impact of climate change on forest-fire danger in Finland by using daily input from five independent general circulation models (GCMs). This allows us to explore the uncertainty ranges related to the projected change in forest-fire danger, an aspect that is poorly covered in the previous studies. In spite of the continuous development of climate models, the range of model uncertainty has not considerably decreased since the 1990s (Räisänen and Ylhäisi, 2015) and with lead times of a few decades, this model uncertainty can account for more than half of the total uncertainty related to climate projections (Hawkins and Sutton, 2009). As the previous studies have, in addition, mainly focused on changes in mean conditions, we direct our special interest to large-scale fires which are more relevant with regard to fire management and ecological consequences. We are moreover motivated by the fact that in countries like Finland, forest-based bioeconomy has a key role in climate change mitigation and it is thus particularly important to understand the impact of climate change on the risks affecting forests and to take them into account in forest management. That is because efficient mitigation requires increasing carbon sequestration and use of forest biomass to substitute fossil-intensive fuels, materials, and products (Kilpeläinen et al., 2015).

In this work, we first use forest-fire statistics from Finland covering 19 fire seasons to study the relationship between weather and fire occurrence in the present climate. Then, we use daily data from five GCMs participating in the Coupled Model Intercomparison Project (CMIP) phase 5 (Taylor et al., 2012) under representative concentration pathway (RCP) scenarios RCP4.5 and RCP8.5 (van Vuuren et al., 2011) to study the impact of climate change on fire occurrence over the period 1980-2099. An intrinsically similar approach has previously been used in studying the impact of climate change on regional fire activity, e.g. by Pereira et al. (2013). In this work, modelled values of weather variables are downscaled onto a high-resolution grid covering Finland using the quantile-mapping approach. In assessing the forestfire potential, we apply the widely used Canadian forest-fire weather index (FWI) system (Van Wagner, 1987), which provides a numerical rating of fire danger, as well as indices for the moisture content of forest fuels.

\section{Materials and methods}

\subsection{Fire statistics}

To study the spatial and temporal occurrence of forest fires in Finland, we used fire data that consisted of fire reports collected from the national Finnish Rescue Service database, available from 1996 onwards. The fire reports include information on date, time, location, burned area, and ignition source of a fire, as well as vegetation type (e.g. forest, clearing, peat land, grassland, park) of a fire site. In this study, we only consider those fires that reportedly burned forested area. The fires that occurred in the autonomous Åland Islands (the group of islands located in the south-westernmost part of Finland, consisting of about $0.5 \%$ of the Finnish land area) were not included in the database.

In most cases, the locations of fires were only given at municipality level prior to 2005 , but thereafter, the exact coordinates of the fire sites were usually provided. In this study, the fires were located on a $0.1^{\circ} \times 0.2^{\circ}$ (approximately $10 \mathrm{~km} \times 10 \mathrm{~km}$ ) latitude-longitude grid. In cases when the spatial coordinates were missing, the fires were assumed to be located in the centroid of the municipality where they had occurred.

According to the statistics, almost 20000 forest fires occurred in Finland from 1996 to 2014. Indeed, 112 of these 
Table 1. CMIP5 models used in this study with information on country of origin and resolution of the models ( $L$ refers to number of vertical levels, $T$ to triangular truncation, and $C$ to cubed sphere).

\begin{tabular}{llll}
\hline Model & Country of origin & Resolution (long $\times$ lat), level & Reference \\
\hline CanESM2 & Canada & T63 $\left(1.875^{\circ} \times 1.875^{\circ}\right)$, L35 & von Salzen et al. (2013) \\
CNRM-CM5 & France & T127 $\left(1.4^{\circ} \times 1.4^{\circ}\right)$, L31 & Voldoire et al. (2013) \\
GFDL-CM3 & United States & C48 $\left(2.5^{\circ} \times 2.0^{\circ}\right)$, L48 & Donner et al. (2011) \\
HadGEM2-ES & United Kingdom & $1.25^{\circ} \times 1.875^{\circ}$, L38 & Collins et al. (2011) \\
MIROC5 & Japan & T85 $\left(1.4^{\circ} \times 1.4^{\circ}\right)$, L40 & Watanabe et al. (2010) \\
\hline
\end{tabular}

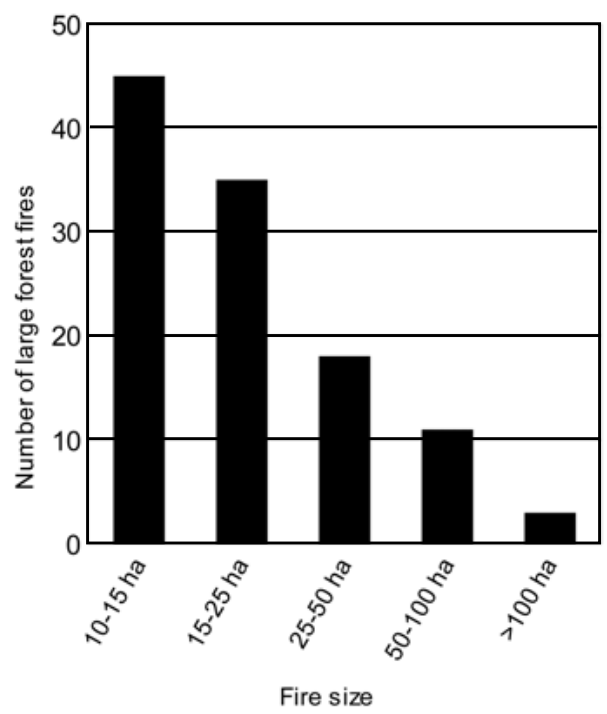

Figure 1. Large forest fires in Finland during 1996-2014 as classified on the basis of fire size.

fires (approximately $0.6 \%$ of all forest fires) burned 10 ha or more forest. Hereafter, we refer to these fires as large forest fires. The largest forest fire in the database burned 200 ha of forest in Tammela in 1997 but most of the large forest fires burned only 10-25 ha (Fig. 1).

\subsection{Climate data}

In order to build a relationship between the fire data and prevailing weather conditions, we used gridded daily weather data covering Finland over the period 1996-2014 for which the fire data existed. Air temperature (daily mean, maximum and minimum) and daily mean relative humidity at a height of $2 \mathrm{~m}$, as well as precipitation, observed by the Finnish Meteorological Institute weather observation network were interpolated onto the same high-resolution $0.1^{\circ} \times 0.2^{\circ}$ grid with the fire data by applying kriging with external drift (Aalto et al., 2013). Because the quality of wind speed observations did not support the creation of a homogenous gridded daily data set for Finland, we used coarser daily wind speed data from the European Centre for Medium-Range Weather Forecasts ERA-Interim reanalysis (Dee et al., 2011). These data were provided on a regular $0.75^{\circ} \times 0.75^{\circ}$ grid and bilinearly interpolated onto the same $0.1^{\circ} \times 0.2^{\circ}$ grid with the abovementioned other variables.

To estimate the effects of changing climate on the forestfire risk, we used daily data from five CMIP5 models (Table 1). The models were chosen on the basis of their skill to simulate the present-day average monthly temperature and precipitation climatology in northern Europe and the availability of all required variables on a daily timescale. Our study period consisted of the years 1980-2099 and historical simulations until 2005 were combined with simulations under RCP4.5 and RCP8.5 emission scenarios (van Vuuren et al., 2011) for the period 2006-2099. Because climate model outputs are often biased high or low in relation to the observed climate (e.g. Cattiaux et al., 2013), and in addition, presented on a relative coarse grid, we performed a combined statistical downscaling and bias correction on the modelled daily values before calculating the forest-fire-risk index. We performed the downscaling onto the Finnish $0.1^{\circ} \times 0.2^{\circ}$ grid by applying a quantile-mapping technique using smoothing (Räisänen and Räty, 2013; Räty et al., 2014).

Figure 2 illustrates projected changes in climate variables in our data set. The mean daily maximum temperature of the forest-fire season is projected to increase in Finland by $1-$ $3{ }^{\circ} \mathrm{C}$ for the period $2010-2039,2-6^{\circ} \mathrm{C}$ for the period 2040 2069 , and $2-8^{\circ} \mathrm{C}$ for the period $2070-2099$, relative to the baseline period 1980-2009 depending on the scenario and model. The projected change is greater in RCP8.5 than in RCP4.5, although there is a considerable amount of variability in the rate of change among different models for temperature and other variables. As for temperature, the projected change is uniformly positive for precipitation. April-October precipitation is likely to increase in Finland by about $20 \%$ by the end of the twenty-first century. For relative humidity, the projections indicate a decrease by $0-6$ percentage points within the present century. For wind speed, the projected changes vary around $0 \%$ with considerable inter-model variation for all periods under both scenarios. Regionally, both temperature and precipitation are projected to increase more in northern than in southern Finland (not shown). Moreover, the projected increases in temperature and precipitation are in general larger for early and late forest-fire season than for the midsummer months. Consequently, in the southern and 
(a)

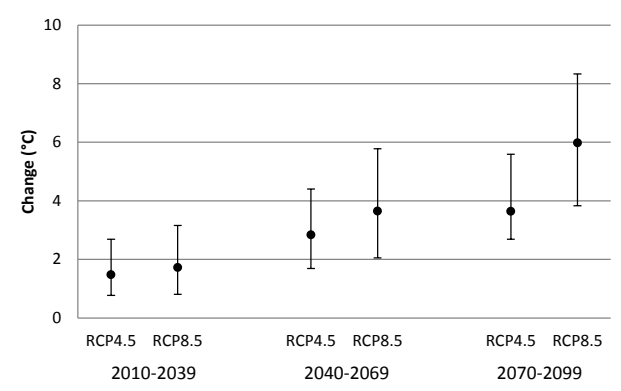

(c)

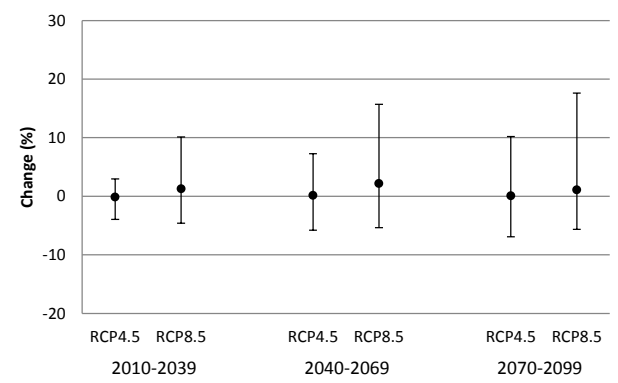

(b) Relative humidity

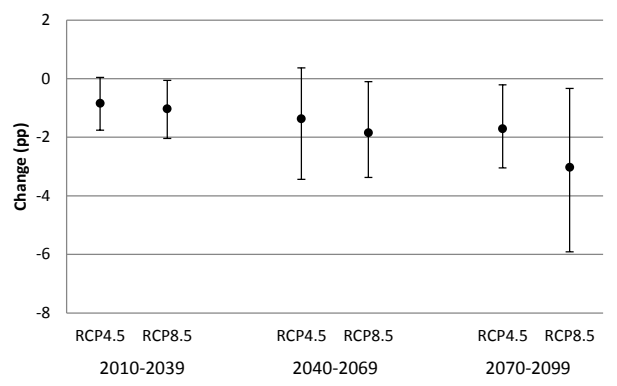

(d) Precipitation

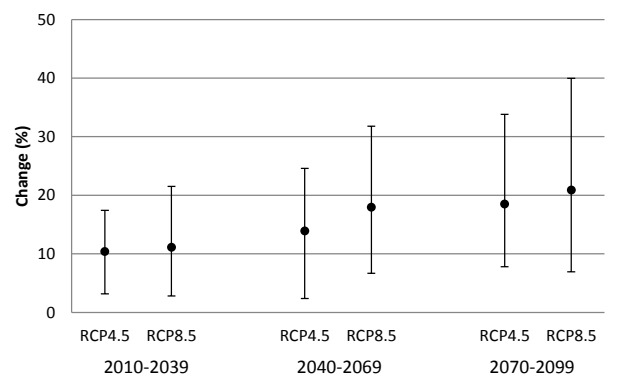

Figure 2. Projected changes in April-October mean daily maximum air temperature at $2 \mathrm{~m}$ (a), daily average relative humidity at $2 \mathrm{~m}$ (b), daily average wind speed at $10 \mathrm{~m} \mathrm{(c),} \mathrm{and} \mathrm{total} \mathrm{precipitation} \mathrm{(d)} \mathrm{compared} \mathrm{to} \mathrm{the} \mathrm{period} \mathrm{1980-2009} \mathrm{and} \mathrm{averaged} \mathrm{over} \mathrm{the} \mathrm{whole} \mathrm{of} \mathrm{Finland.}$ Dots indicate the multi-model mean change and whiskers extend to the maximum and minimum projections.

eastern parts of the country, precipitation may even decrease between June and August.

\subsection{Forest fire risk assessment based on the fire weather index system}

We assessed the forest-fire risk by applying the FWI system following Van Wagner and Pickett (1985). In the FWI system, three soil moisture codes are calculated on a daily basis based on air temperature, relative humidity, and wind speed observations at local noon and the total precipitation sum of the preceding $24 \mathrm{~h}$. Affected by wind speed, these codes are then converted into three fire behaviour indices. The final FWI rating is a dimensionless quantity indicating the likely intensity of fire. The FWI rating can be further converted into daily severity rating (DSR) according to

$\mathrm{DSR}=0.0272 \times \mathrm{FWI}^{1.77}$.

The DSR emphasizes higher FWI values through the power relation and reflects the expected efforts required for fire suppression more accurately than FWI. The DSR can be averaged over time to give the seasonal severity rating (SSR):

$\mathrm{SSR}=\sum_{i=1}^{n} \mathrm{DSR}_{i} / n$, where $\mathrm{DSR}_{i}$ is the DSR value for the $i$ th day, and $n$ is the total number of days. The DSR averaged over a 1 month period is referred to as the monthly severity rating (MSR).

Because climate model data were provided as daily mean values, we converted the daily means of relative humidity and wind speed to correspond to the afternoon values better and took advantage of available daily maximum temperature data by using the bias-corrected daily maximum temperatures for calculating the FWI. The bias-corrected precipitation sums were used unaltered since $24 \mathrm{~h}$ precipitation sums are intended to be used in the FWI system. In converting the daily means of relative humidity into afternoon values, we used daily maximum temperatures and assumed specific humidity to stay constant throughout a day. In the case that this lead to night-time supersaturation according to the bias-corrected daily minimum temperatures, the moisture content of air at night was reduced to give a maximum relative humidity of $100 \%$ at the time of the minimum temperature. The moisture content of air at the time of maximum temperature was correspondingly increased so that the daily mean specific humidity remained unaltered. To reflect the diurnal cycle in wind speed, we simply multiplied the bias-corrected daily mean wind speeds by 1.2, as on average, wind speed peaks in the early afternoon in phase with diurnal cycle of near-surface air temperature. This was based on 30 years (1980-2009) of meteorological observations from four locations (Vantaa, Jokioinen, Jyväskylä, and Sodankylä) across Finland, which 

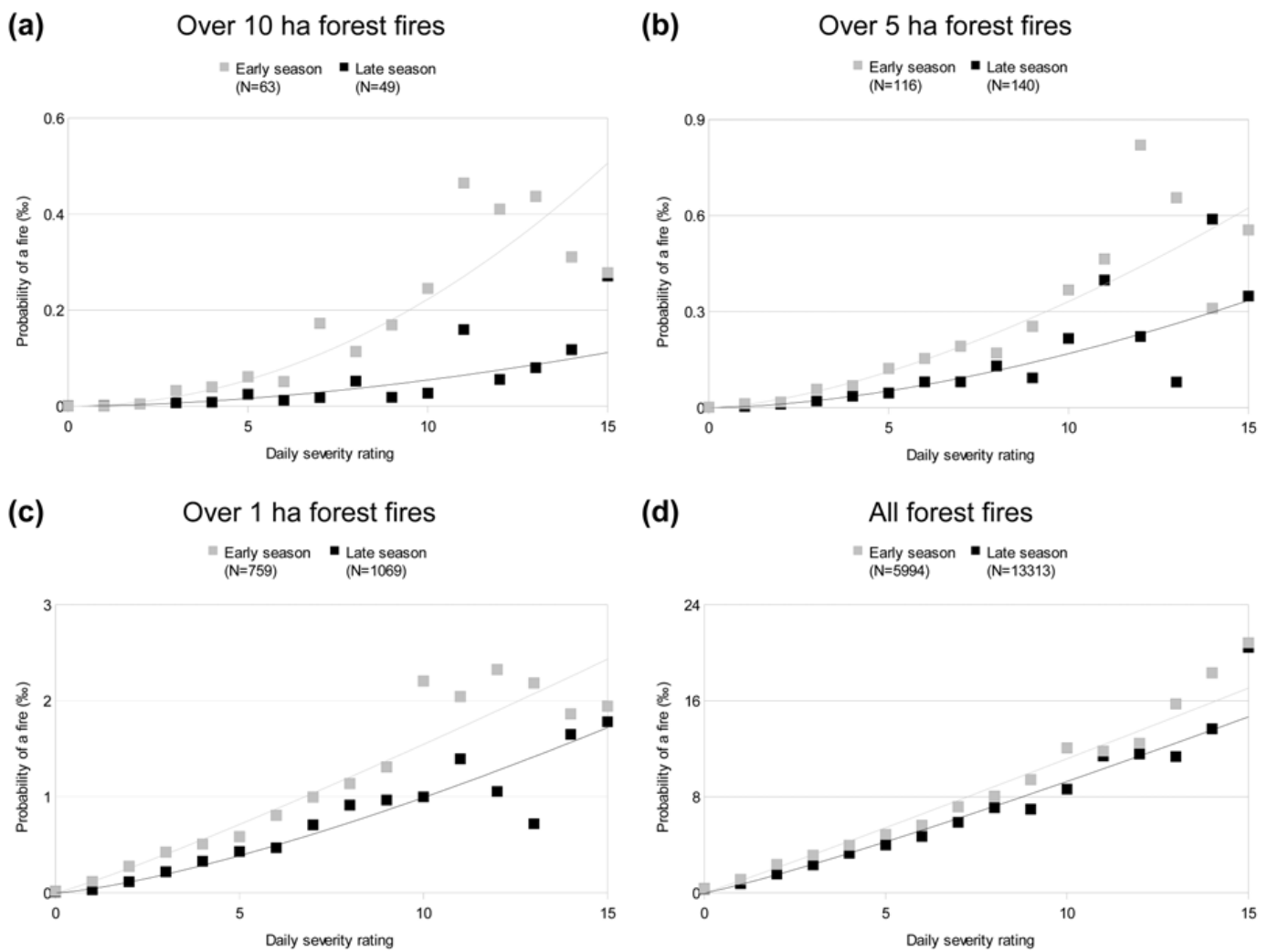

Figure 3. The relationship between daily severity rating (DSR) and occurrence of forest fires of different size in Finland during 1996-2014, performed separately for the early (effective temperature sum below $250^{\circ} \mathrm{C}$ days; grey squares) and late season (effective temperature sum above $250^{\circ} \mathrm{C}$ days; black squares). (a) Forest fires over 10 ha (i.e. large forest fires). (b) Forest fires over 5 ha. (c) Forest fires over 1 ha. (d) All forest fires. The numbers of fires in each class is shown as well.

showed that on average, wind speed exceeds the daily mean in the afternoon by about $20 \%$. The same set of observations also showed that the procedure of transforming daily mean relative humidities into afternoon values was valid and produced correct results, on average.

\subsection{Regression models for fire-danger estimations}

In order to estimate the impact of climate change on fire danger, we first compared the gridded DSR values with the information on locations of forest fires during 1996-2014. As the ignition probability with the same FWI value varies considerably between different stages of seasonal vegetation development (Tanskanen and Venäläinen, 2008), the inspection was performed separately for the early and late season (Fig. 3). We used the early season probability from the beginning of the growing season until the effective temperature sum reached 250 degree days when understorey vegetation is fully developed (Tanskanen and Venäläinen, 2008). In the current climate, this happens over most of Finland typically during the first half of June. Then, the late season probability was used until the end of October when the forest-fire season in Finland is virtually over (Tanskanen and Venäläinen, 2008). The commencement of the growing season was annu- ally defined to occur on a date, which after daily mean temperature, remained above $5^{\circ} \mathrm{C}$ on average. In general, the ignition probabilities were higher during the early season than the late season. Moreover, the larger the fires that were inspected, the larger this difference was. Among the tested relations (linear relation, exponential relation, and power-law relation), the ignition probabilities best followed the powerlaw relation as a function of DSR. For large forest fires (i.e. fires over $10 \mathrm{ha}$ ), the occurrence probability in a single grid cell in a given day as a function of DSR was estimated via the power relation:

$$
\begin{aligned}
& P(\mathrm{DSR})=0, \text { when } \mathrm{DSR}=0 \\
& P(\mathrm{DSR})=a \times \mathrm{DSR}^{b}, \text { when } 0<\mathrm{DSR} \leq 15 \\
& P(\mathrm{DSR})=a \times 15^{b}, \text { when } \mathrm{DSR}>15 .
\end{aligned}
$$

For the early season, we used the coefficients $a=0.002114452978079$ and $b=2.02257786261162$ and for the late season $a=0.000919759277827$ and $b=1.77233673026624$. By summing the probabilities over the whole of Finland (excluding the Alland Islands) and the fire season, we modelled the annual number of large forest 
(a)

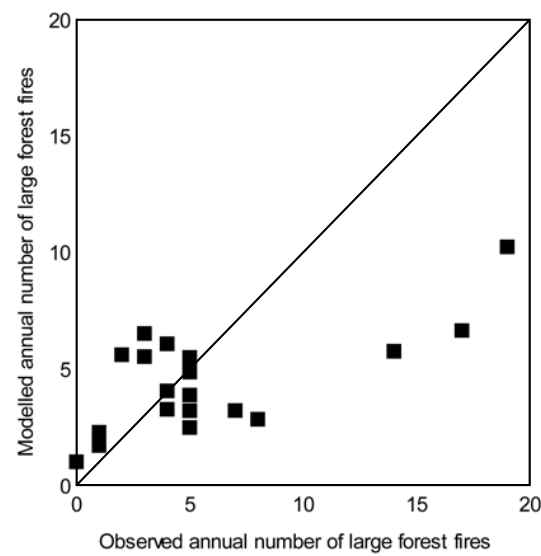

(b)

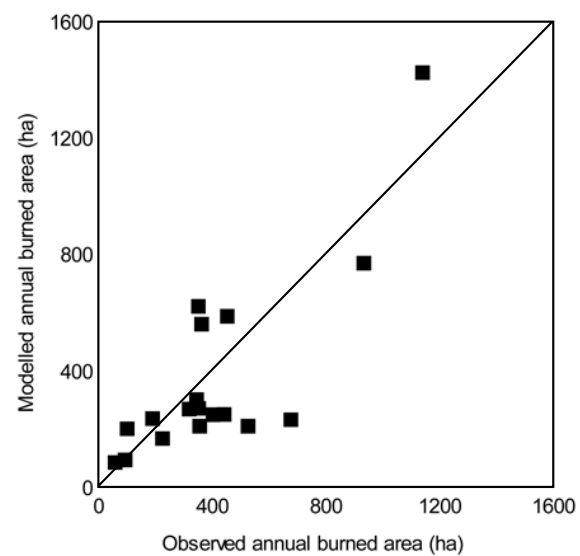

Figure 4. (a) Modelled annual number of large forest fires as a function of observed annual number of large forest fires in Finland during 1996-2014. (b) As in (a) but for annual burned area.

Table 2. Coefficients $a$ and $b$ used in Eq. (4) to estimate the total burned area by month as a function of MSR averaged over the whole of Finland. $R^{2}$ is the coefficient of determination.

\begin{tabular}{lrrc}
\hline Month & $\mathrm{a}$ & $\mathrm{b}$ & $R^{2}$ \\
\hline April & 69.58 & 1.97 & 0.54 \\
May & 52.96 & 1.07 & 0.28 \\
June & 6.85 & 2.71 & 0.67 \\
July & 7.67 & 2.58 & 0.83 \\
August & 10.33 & 2.61 & 0.56 \\
September & 16.37 & 2.97 & 0.67 \\
October & 7.96 & 1.23 & 0.42 \\
\hline
\end{tabular}

fires in Finland. As only $0.2 \%$ of considered days (and $8 \%$ of large forest fires) showed a DSR above 15, we assumed the fire probability to stay constant when the DSR was above 15 , as it was hard to say whether the same power relation still applies with such high DSR values. Nevertheless, we repeated all of our calculations, assuming that the power relation would hold with DSRs above 15 and the estimated numbers of large forest fires were only limitedly increased because high DSRs occur relatively seldom.

A similar power relation was created to estimate the annual burned area in Finland based on MSRs averaged over the whole of Finland from April to October:

$A(\mathrm{MSR})=a \times \mathrm{MSR}^{b}$

where $A$ is the monthly burned area in hectares. We defined the coefficients $a$ and $b$ separately for each month (Table 2) and estimated the annual burned area by summing the estimated burned areas in each month.

Performance of the regression models is illustrated in Fig. 4 and the statistics for model validation are summarized in Table 3. In general, the regression model for burned area showed higher correlation with observations than the model for the number of large forest fires. In addition, the highest annual peaks in the number of large forest fires are underestimated, leading to a negative mean bias error. The nonparametric Spearman's rank correlations between the models and observations were weaker than the parametric Pearson's correlations. Nevertheless, the Spearman's correlation for burned area was still statistically significant at $1 \%$ level.

\subsection{Data analysis}

First, we studied the distribution of large forest fires in Finland and the fire activity with regard to population density based on the fire statistics during 1996-2014. We assumed that no significant impact on the fire regime is caused due to differences in fuel amount or type because forest fuels are relatively similar throughout Finland with the exception of the tundra vegetation in northernmost Lapland above $68^{\circ} \mathrm{N}$ (Reinikainen et al., 2000). Then, we used Eqs. (3) and (4) to estimate the number of large forest fires and burned area in Finland until 2099 by utilizing the climate model data.

\section{Results}

\subsection{Fire regime in Finland}

The distribution of large forest fires in Finland during 19962014 is shown in Fig. 5a along with population density. The average size of forest fires in Finland steadily decreases with increasing population density (Fig. 5b), while the population density tends to strongly decrease towards the north. Hence, although the occurrence of forest fires has a strong positive correlation $\left(R^{2}=0.85\right)$ with population density on a regional scale (Fig. 5c), this dependency is largely absent when con- 
Table 3. Statistics for the model validation over the period 1996-2014.

\begin{tabular}{lrrrr}
\hline & Pearson correlation & Spearman correlation & Mean bias error & Root-mean-square error \\
\hline Large forest fires & $0.67^{* *}$ & $0.39^{*}$ & -1.43 & 4.25 \\
Burned area & $0.81^{* * *}$ & $0.58^{* *}$ & -34.34 & 184.87 \\
\hline
\end{tabular}

Asterisks denote statistical significance $\left.{ }^{*} p<0.1 ;{ }^{* *} p<0.01 ;{ }^{* * *} p<0.001\right)$.
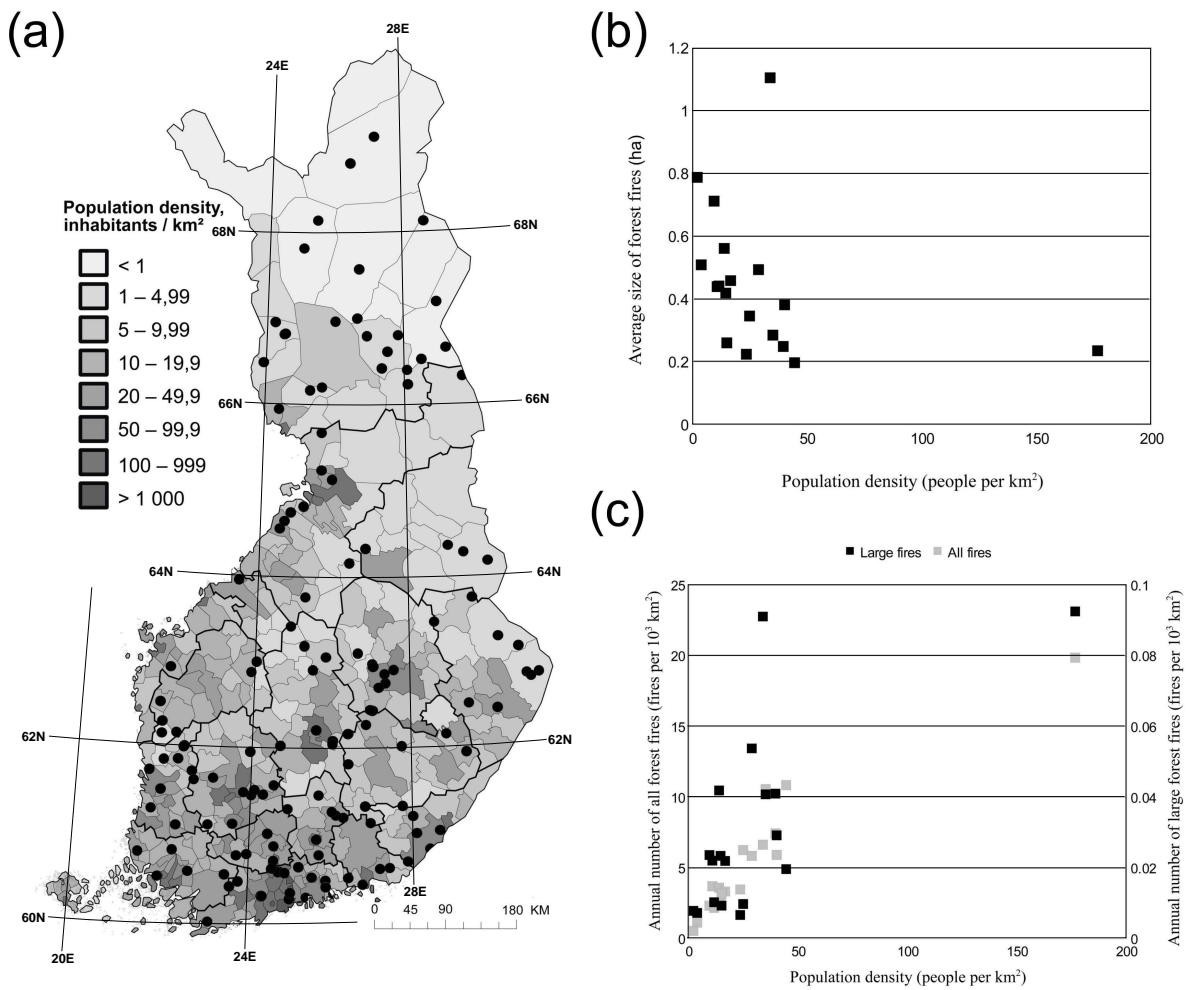

Figure 5. (a) Locations of large forest fires in Finland during 1996-2014 along with population density by municipality. (b) Average size of forest fires in Finland by region during 1996-2014 as a function of population density. (c) Annual mean number of all forest fires (grey squares) and large forest fires (black squares) per $10^{3} \mathrm{~km}^{2}$ in Finland by region during 1996-2014 as a function of population density.

sidering large forest fires. This is one reason why we decided to use 10 ha as a threshold for large forest fires.

Figure 6 shows MSRs based on observational weather data during 1996-2014 along with monthly burned forest areas. As seen in Table 2, the burned area correlates best with MSR in July and worst in May. In general, variations in the annual burned area reflect variations in SSR fairly well. The Pearson product-moment correlation coefficient between these two variables proved to be as high as 0.75 during 1996-2014. Nevertheless, when the annual burned area is estimated on the basis of MSRs by using Eq. (4), the correlation with the actual burned area is even higher (0.81; Table 3$)$.

Annual modelled and observed numbers of large forest fires and burned area in Finland during 1996-2014 are displayed in Fig. 7. As can be expected based on the positive correlations in Table 3, the modelled fire activity follows the observed fire activity well enough to depict the main tem- poral variations. The highest modelled annual peaks in the number of large forest fires are underestimated largely due to weak correlation between the fire weather and occurrence of large forest fires in May. For instance, in 1997 and 2008, two years with relatively many large forest fires, all large forest fires occurred before mid-June and most of them in May. However, May and early June also displayed similarly dry fire weather conditions in 1999, 2000, and 2002; but only a few large forest fires occurred during these years.

Classification of large forest fires based on the reported ignition source reveals interestingly that early season fires are almost entirely human-induced; whereas in July, most large forest fires are ignited by a lightning strike (Fig. 7c). Outstandingly common human-caused large forest fires are in May and early June. The large majority of all human-caused large forest fires in Finland during 1996-2014 occurred during this relatively short period. At that time of year, the large 

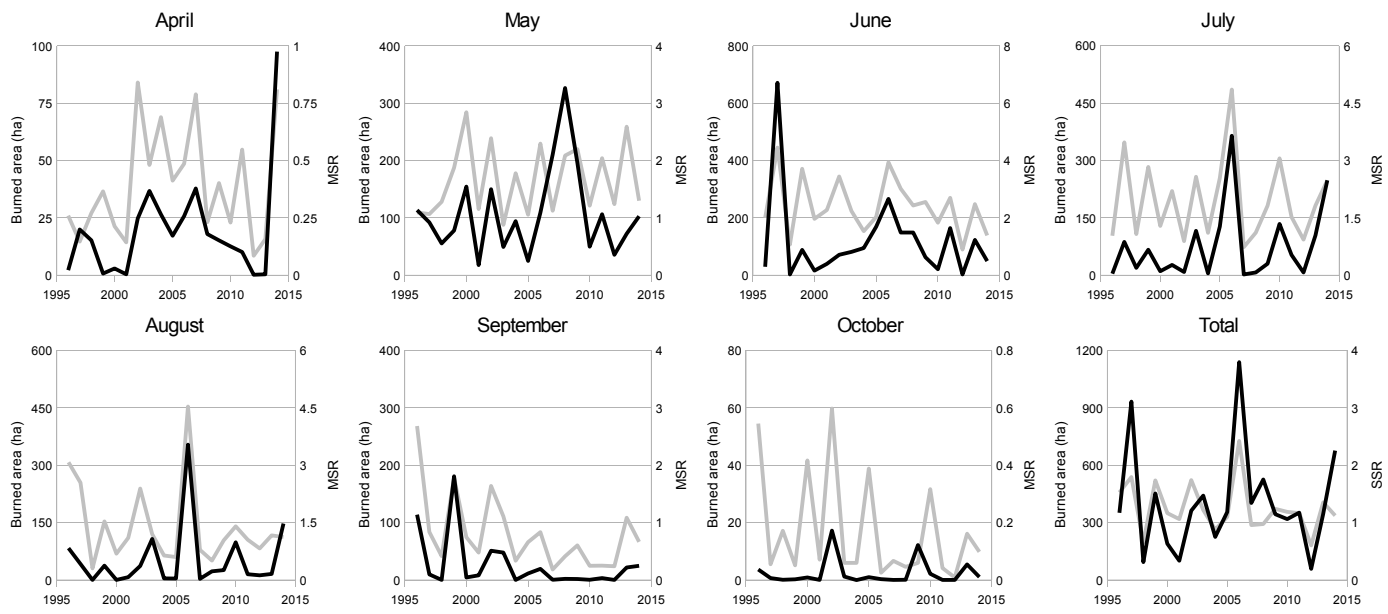

Figure 6. Burned forest area (black lines) in Finland by month and monthly severity rating (grey lines) averaged over the whole of Finland during 1996-2014.

(a)

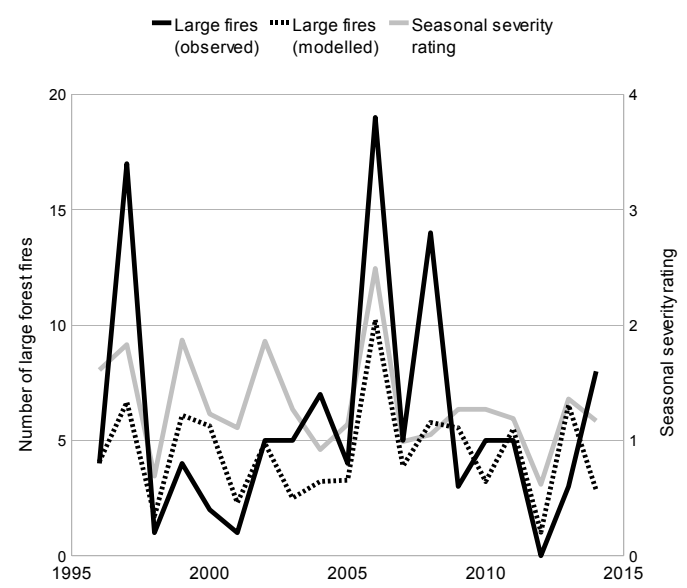

(b)

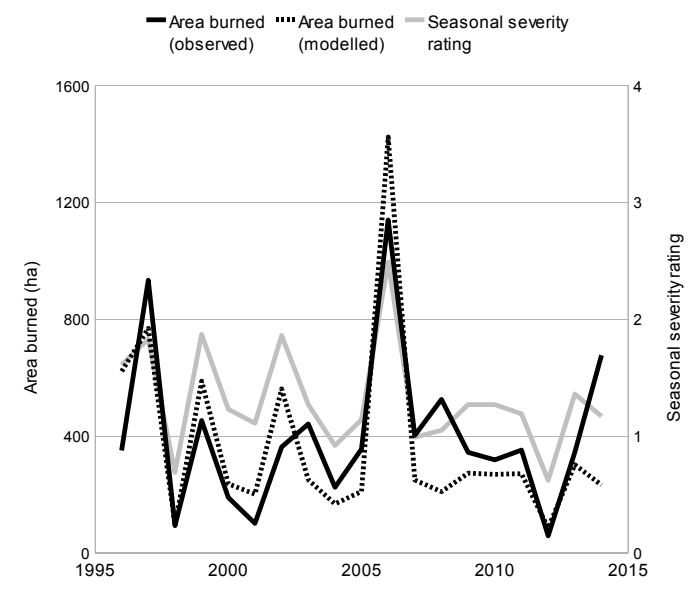

(c)

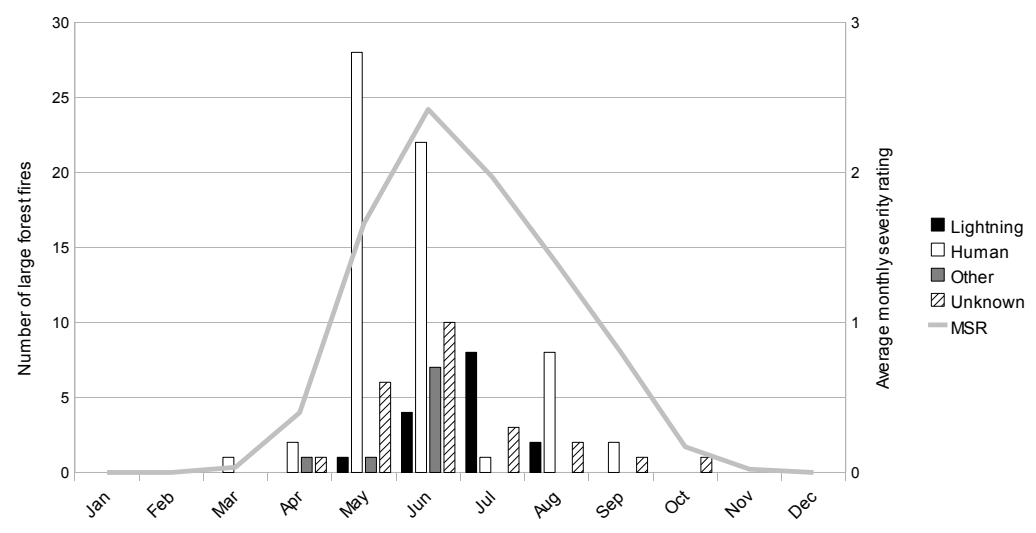

Figure 7. (a) Annual observed (solid black line) and modelled (dashed black line; based on Eq. 3) numbers of large forest fires in Finland during 1996-2014, as well as the annual April-October seasonal severity rating averaged over the whole of Finland (grey line). (b) Annual observed (solid black line) and modelled (dashed black line; based on Eq. 4) area burned in Finland during 1996-2014, as well as the annual April-October seasonal severity rating averaged over the whole of Finland (grey line). (c) Nationwide average of monthly severity rating (MSR) in Finland during 1996-2014 (grey line) and monthly distribution of large forest fires in Finland within the same period, divided by the source of ignition (bars). 
Table 4. Proportions (in \%) of forest fires of different sizes, divided according to the daily severity index (DSR) classes in Finland during 1996-2014.

\begin{tabular}{lrrrrr}
\hline DSR & $<1$ ha & $1-5$ ha & $5-10$ ha & $10-20$ ha & $>20$ ha \\
\hline$<1$ & 96.4 & 3.2 & 0.2 & 0.2 & 0.0 \\
$1-5$ & 90.8 & 8.2 & 0.6 & 0.3 & 0.1 \\
$5-10$ & 87.6 & 10.5 & 1.1 & 0.4 & 0.4 \\
$>10$ & 89.2 & 8.1 & 1.2 & 0.7 & 0.8 \\
\hline
\end{tabular}

fires tend to be often caused by escalated prescribed burning or the burning of rubbish. These activities are not practised anymore later in summer.

The average size of forest fires in Finland increases with increasing severity of prevailing fire weather. The large majority of all forest fires still burn less than 1 ha of forest with high DSR values, but the share of large forest fires (we recall that with large forest fires, we refer to all forest fires larger than 10 ha) increases from 0.2 to $1.5 \%$ when the DSR increases from below 1 to over 10 (Table 4).

\subsection{Projected climate change impact on the forest-fire risk}

The SSR averaged over the April-October period likely already increased during the early twenty-first century, and by the period 2070-2099, the nationwide multi-model mean change exceeds $100 \%$ under the RCP8.5 scenario (Fig. 8a). However, among different model projections, the increase varies between 28 and $200 \%$. For the number of large forest fires, the projected change is slightly larger than for SSR (Fig. 8b). For instance, under the RCP8.5 scenario the range for the projected increase from 1980-2009 to 2070-2099 is from 54 to $238 \%$. For the burned area, future estimates have a huge variability among different model projections (Fig. 8c). Already by the period 2010-2039, the projected change varies approximately between 5 and $200 \%$. By the period 2070-2099, the burned area is projected to increase under the RCP 8.5 scenario by $35-1271 \%$, depending on the model, and under the RCP4.5 scenario by $56-441 \%$. However, as the burned area has been small during recent years, even a single fire comparable in size to the Västmanland wildfire in Sweden in 2014 would burn about twice as much forest area than was burned in Finland during the years 19962014 in total. Hence, occurrence of only a couple of conflagrations could lead to an increase of hundreds of percent in the burned area. For all statistics, the projected multi-model mean change and the range among different model projections are smaller under the RCP4.5 than RCP8.5 scenario.

Regionally, the forest-fire danger is projected to increase rather similarly throughout Finland (Fig. 9). Under the RCP8.5 scenario, multi-model mean SSR averaged over the April-October period increases in the south from about 2-3

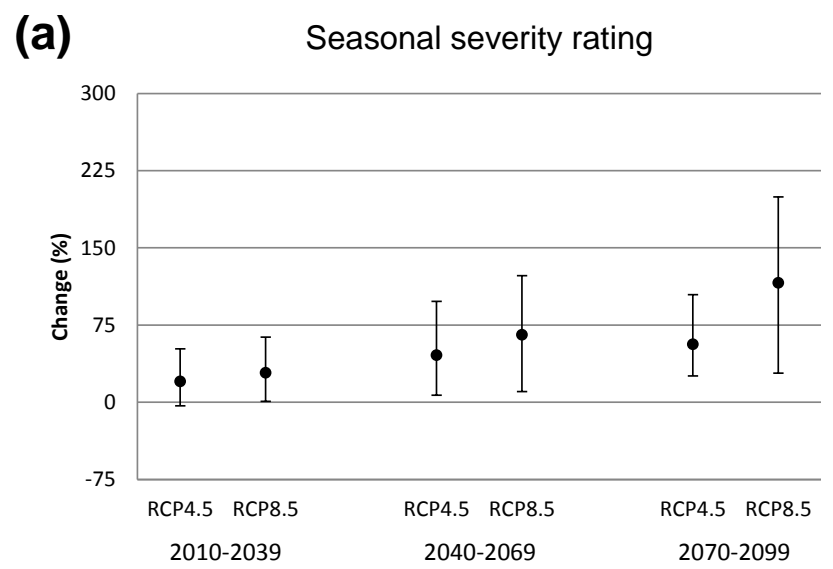

(b) Number of large forest fires

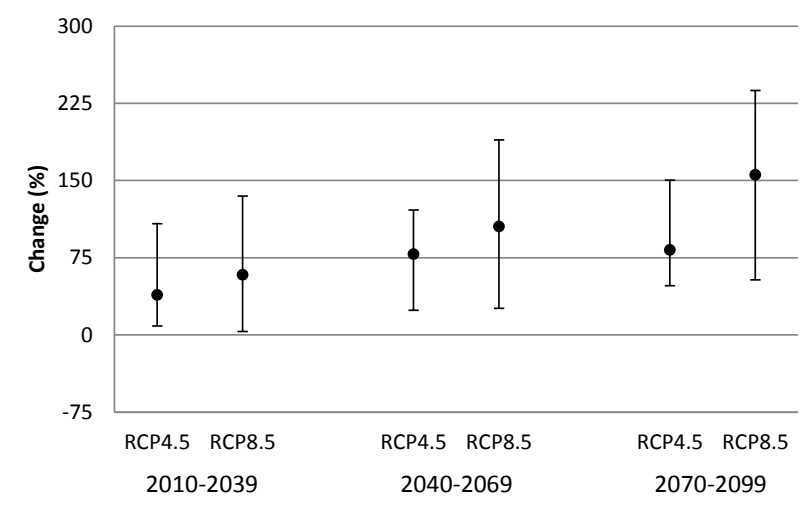

(c) Area burned

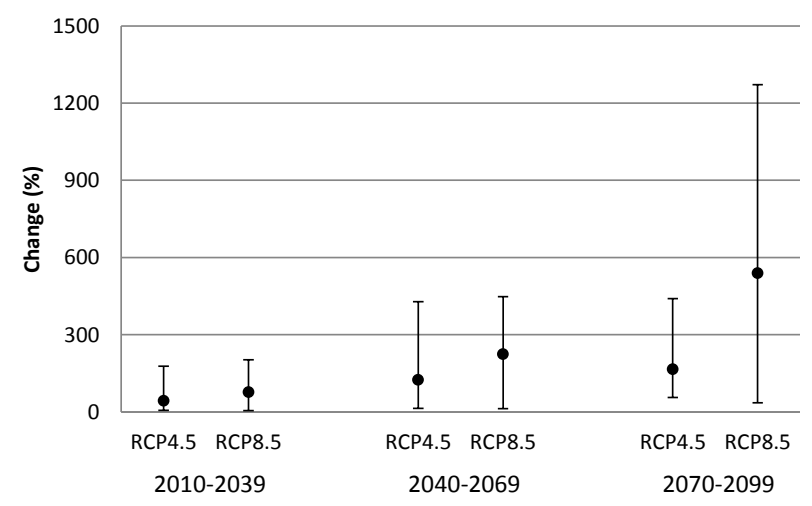

Figure 8. Projected changes in April-October seasonal severity rating averaged over the whole of Finland (a), in the number of large forest fires in Finland (b), and in the area burned (c) compared to the period 1980-2009. Dots indicate the multi-model mean change and whiskers extend to the maximum and minimum projections. 
Table 5. The 90th, 50th, and 10th percentiles of multi-model mean annual number of large forest fires in Finland, excluding the Åland Islands. The range in the number of modelled large forest fires among the model projections is shown in parentheses.

\begin{tabular}{lrrrr}
\hline & RCP4.5 1980-2009 & RCP4.5 2010-2039 & RCP4.5 2040-2069 & RCP4.5 2070-2099 \\
\hline 90th percentile & $11(6-18)$ & $12(10-15)$ & $15(13-18)$ & $14(12-16)$ \\
50th percentile & $5(4-6)$ & $6(5-7)$ & $9(5-10)$ & $9(8-9)$ \\
10th percentile & $2(1-2)$ & $3(2-4)$ & $5(2-6)$ & $4(3-6)$ \\
\hline & RCP8.5 1980-2009 & RCP8.5 2010-2039 & RCP8.5 2040-2069 & RCP8.5 2070-2099 \\
\hline 90th percentile & $9(7-11)$ & $15(11-24)$ & $16(12-20)$ & $18(11-21)$ \\
50th percentile & $4(4-5)$ & $7(4-10)$ & $10(6-14)$ & $12(8-16)$ \\
10th percentile & $2(1-2)$ & $3(2-4)$ & $5(4-8)$ & $7(4-12)$ \\
\hline
\end{tabular}

to 4-6 and in the north from about 1 to 2 until the end of the twenty-first century; i.e. it approximately doubles.

Moreover, the fire danger is projected to increase both during the driest and wettest summers but in relative terms, the number of large forest fires is expected to increase most in the summers that express a relatively small number of large fires (Table 5). In spite of large inter-model variability, the number of large forest fires during a typical year in the late 21 st century is expected to be close to what it was was during the recent years that experienced the highest number of large forest fires (e.g. 1997, 2006 and 2008). Similarly, the easiest future fire seasons would be comparable to the current average fire seasons.

\section{Discussion and conclusions}

\subsection{Evaluation of methodology}

In this study, we used statistically downscaled climate model simulations to evaluate the impact of climate change on the number of large fires and total burned area in the boreal forests of Finland. In assessing the fire risk, we applied the FWI system, and the statistical downscaling was performed with the quantile-mapping technique. Quantile mapping has proven to be among the best-performing empirical bias-correction methods for temperature (Räisänen and Räty, 2013) and precipitation (Räty et al., 2014) throughout the probability distribution and it has been suggested the most in recent studies (e.g. Teutschbein and Seibert, 2012). Quantile mapping has also been previously successfully applied for correcting relative humidity and wind speed simulations (Wilcke et al., 2013). Moreover, Yang et al. (2015) used a rather similar approach for correcting regional climate model output in order to assess forest-fire risk in Sweden. However, the method is still by no means perfect. Where the local differences between simulated and observed climates are fairly large, the downscaling technique is less likely to yield accurate results. In Finland, these areas include many coastal regions and, in addition, northernmost Lapland, where the relatively scarce station density is compounded with com-
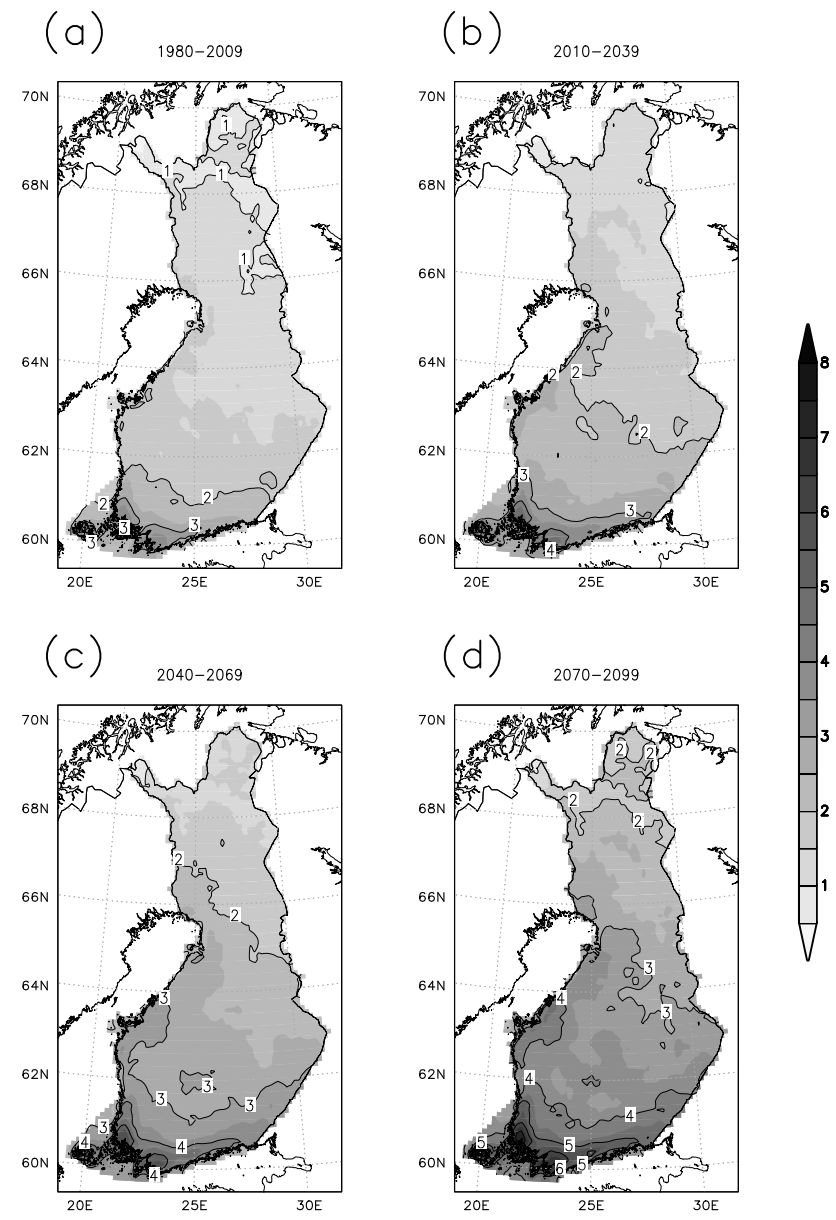

Figure 9. Projected multi-model mean for the April-October seasonal severity rating (SSR) in 1980-2009 (a), 2010-2039 (b), 2040-2069 (c), and 2070-2099 (d) under the RCP8.5 scenario. 
plex topography. One shortcoming of the quantile-mapping method is that averaging the downscaled time series back to the original resolution leads to overestimation of extreme values if the variable in question has much small-scale variability (Maraun, 2013). This holds particularly for precipitation. This effect is only visible for the area-averaged time series, and in the present study, it probably somewhat increased the inter-annual variability in the fire weather projections.

The FWI system applied in fire-risk estimation was initially developed empirically for Canadian boreal conditions, but it has become widely implemented in other countries around the world as well. Eventually, the FWI system has been suggested as the basis for a global early warning system for wildland fires (de Groot et al., 2006). Comparison of FWI to the forest-fire index used operationally in Finland revealed that the two indices perform similarly in Finnish conditions (Vajda et al., 2014).

The developed regression models for estimation of the number of large forest fires and burned area have marked uncertainties. Firstly, the period consisting of information on fire locations and used in developing the regression models is fairly short, only 19 years. Secondly, it is uncertain that a similar relationship between fire weather and fire activity would still hold in the future if the fire weather turns much more severe. However, as most of large forest fires occur when the fire danger is only moderately high, the change in the most extreme conditions has less relevance because those situations will, in any case, occur relatively rarely. Thirdly, weather explains only a part of the variability in fire activity. Our results suggest that roughly about half of the variability in the annual burned area can be explained by variations in MSRs, but in the long term, other factors may be more important.

The use of the DSR instead of FWI ameliorated our results: the correlation between annual burned area and SSR $(\sim$ $0.75)$ was larger than reported by Venäläinen et al. (2014) between annual burned area and seasonal mean FWI $(\sim 0.60)$ in Finland. By taking into account the seasonal variations in the correlations between fire activity and fire-danger indices, limited improvements were achieved in the performance of our regression models; though this is also one source of uncertainty. Currently, most large forest fires in Finland occur within a relative short period in May and early June as a result of human activities, often including prescribed burning and the burning of rubbish. It may have an impact on the fire activity whether these activities are still conducted during the same time of year in the future or whether they will be preponed as the commencement of the growing season is projected to take place earlier in a warmer climate (Ruosteenoja et al., 2011). In addition, the correlation between fire activity and fire danger was poorest during this time of year, indicating that the use of fire by humans is probably reduced while the fire danger is high. Later in summer, when lightning is more important cause of large forest fires, fire-danger indices correlate much better with the observed fire activity.
Consequently, the projected increase in the burned area is, by a large part, caused by the projected increase in fire danger during midsummer and late summer.

\subsection{Evaluation of main results}

In accordance with previous studies (Kilpeläinen et al., 2010; Lehtonen et al., 2014b; H. M. Mäkelä et al., 2014), we found that in response to climate change, the forest-fire risk in Finland will increase with a high probability. In these previous studies, the projected change in fire danger was converted into the change in the number of days expressing a high forest-fire danger. Because extreme conditions are more relevant with regard to fire management efficiency, we estimated the climate change impact on potential large-scale forest fires and burned area. Our results suggest that the number of large forest fires could easily double by 2100 , but there is large variability in the projected change among different models and also between the two emission scenarios considered here. Hence, the change can be, in the worst case, even larger. This large inter-model variability is already evident with the subset of five different GCMs used in this study. Within a larger model set, this variability would probably be even larger. To exemplify this, based on results of a single climate model, Yang et al. (2015) estimated that northern Sweden, which is in close proximity to Finland, would face lower fire risk in the future than today. It was mainly because in their simulation, climate was projected to become more humid, while our projections indicated either drier future conditions or little change in relative humidity. In general, the large uncertainty ranges related to the fire-danger projections reflect that uncertainties related to changes in temperature, precipitation, wind, and humidity climates all add uncertainty to the estimation of forest-fire danger. Possible changes in wind climate are particularly important because the FWI rating has been found to be most sensitive to wind speed (Dowdy et al., 2010) and as the multi-model mean change for wind speed is close to zero, it is uncertain whether the actual change will be positive or negative.

The estimates given for burned area are highly uncertain, mostly because the occurrence of only a few conflagrations would increase the burned area from the present level by hundreds of percent. Nevertheless, the likely increase in the number of large fires driven by general increase in the fire danger increases the probability that some of these fires would escalate to conflagrations. It is thus of the utmost importance to suppress the fires as quickly as possible, which may prove to be problematic if multiple fires are ignited within a short time in isolated locations.

Considering the multi-model mean, the present projections for the number of large forest fires and burned area clearly show larger increases than previously estimated for the increase in the number of fire-danger days. This is partly because a larger portion of all fires spread into large fires when fire weather becomes more severe. An additional explanation 
is that the RCP8.5 scenario is a more extreme climate change scenario than any of the scenarios used in the previous studies which applied the Special Report on Emission Scenarios (SRES) (Nakićenović et al., 2000). While based on the multimodel mean under the high-emission SRES A2 scenario, summer temperatures in Finland were projected to increase by about $3{ }^{\circ} \mathrm{C}$ by the end of the present century (Giorgi and Coppola, 2009); this increase is almost $5^{\circ} \mathrm{C}$ in the RCP8.5 scenario (Cattiaux et al., 2013). Moreover, among the models involved in this study, the warming is, on average, slightly larger. Actually, the projected summertime warming in Finland under the RCP4.5 scenario corresponds closely to that under the SRES A2 scenario. For wind speed, relative humidity, and precipitation, the projected changes among the models involved were, on average, rather similar to projected changes from the multi-model means under the SRES scenarios (Gregow et al., 2012; Ruosteenoja and Räisänen, 2013; Lehtonen et al., 2014a).

The impact of climate change on the annual burned area has been previously estimated with the FWI system in North America (Flannigan et al., 2005; Balshi et al., 2009) and in the Mediterranean region (Amatulli et al., 2013). Flannigan et al. (2005) suggested that in Canada, the annual burned area could approximately double by the end of this century, and an even greater increase was projected by Balshi et al. (2009). Recently, Migliavacca et al. (2013) estimated the future burned area in Europe by using a land-atmosphere model that computes the probability of fire occurrence as the product of three terms: the probability related to biomass availability, the probability conditioned on the moisture, and the probability of ignition. They demonstrated that a reduction in productivity reduces the increase in fire activity over semiarid regions, but this is unlikely to happen in northern Europe where forest productivity and biomass stock are projected to increase under a warming climate (Kellomäki et al., 2008; Dury et al., 2011), increasing the forest-fuel load. In northern Europe, Migliavacca et al. (2013) found temperature to be the most important driver of fire activity. For burned area, their results curiously showed an abrupt doubling of the annual burned area in northern Europe around 2010 and no coherent change after that under the modest SRES A1B emission scenario.

Our results indicating substantial increase in the number of large forest fires and burned area in Finland due to a warming climate are generally quantitatively similar with the findings of the above-mentioned studies. The projected increase in fire danger is essentially due to the reduction in forestfuel moisture content. Previously, Dai (2013) has shown that CMIP5 models consistently project soil moisture to decrease over all of Europe. In Finland, the drying of soil is mostly a result of the increase in evaporative demand exceeding the increase in precipitation. In the future, the fire season is also expected to start earlier because of earlier snowmelt (Räisänen and Eklund, 2012) and earlier commencement of the growing season (Ruosteenoja et al., 2011). In autumn, a considerable lengthening of the fire season is not probable because air humidity increases towards winter due to a shortening of the day length.

Tanskanen and Venäläinen (2008) had previously demonstrated that there are three peaks in annual fire activity in Finland: the first in late May and early June, the second after mid-July, and the third in September. They did not directly inspect the ignition sources of fires but hypothesized that the second peak may be associated with lightning, and the last peak, mainly consisting of small-scale fires, would occur because as a result of the open season for elk hunting, as well as various gathering activities, people fill the forests and light campfires. Consistent with their hypothesis, we showed that most large fires in July are ignited by lightning strikes. Moreover, the annual course of lightning-ignited large forest fires follows the annual lightning activity closely, with a peak in July (A. Mäkelä et al., 2014). The first and most prominent peak in fire activity in late May was considered surprising by Tanskanen and Venäläinen (2008) because May had previously been considered a marginal part of the fire season. They assumed that the majority of fires originating from silvicultural slash burning of cured vegetation and rubbish are likely to occur during this time of year. Again, our results confirm this assumption: the large fires in May and early June are almost entirely human-caused, and mainly because of the above-mentioned activities. Moreover, because humans ignite many more large fires before mid-June than later in summer, the seasonal vegetation development might not be the main reason for the higher ignition probabilities in the early season found in fire statistics.

\subsection{Conclusions}

The impact of climate change on forest-fire danger in Finland with emphasis on large-scale fires and model-based uncertainty was studied using the statistically downscaled and bias-corrected daily output of five CMIP5 models. The regression models for estimating the number of large forest fires and burned area were constructed based on the fire statistics covering the years 1996-2014. Our results show that the number of large forest fires may double or even triple by the end of this century but above all, the projections show large inter-model variability. Because of several uncertainties related to this study, the results should be considered to be only approximate; though they highlight the large uncertainty in the rate of the projected increase of forest-fire danger, which is moreover only partly covered by climatological factors considered in this study.

Our results largely confirmed the previous presumptions of Tanskanen and Venäläinen (2008) about the ignition sources of fires at different times of the year. Human-caused large fires are greatly over-represented in late May and early June; whereas in July, lightning ignites the majority of large fires. We also showed that the correlation between fire activity and fire weather indices is poorest in May when humans ignite 
more large fires than during any other month. However, our results did not indicate that population density is a key driver in the occurrence of large forest fires in Finland. That is because although the number of forest fires steadily increases with increasing population density, the average size of fires simultaneously decreases.

Climatological conditions do not prevent conflagrations from occurring in Finland. An increase in fire danger increases the proportion of large-scale fires because the fire managers have less time to suppress the fires if the conditions for vigorous spread of fire are favourable. Even a single conflagration could burn more forest area than has been typically burned within 1 decade in Finland during the last half a century. Our results suggest that the probability of such an event occurring will increase. For the highest projections of burned area to become realized, some fires comparable to the Västmanland wildfire would virtually be required to take place during the present century.

Acknowledgements. This research has been supported by the Consortium project ADAPT (Adaptation of forest management to climate change: uncertainties, impacts, and risks to forests and forestry in Finland), which is a collaboration project between the University of Eastern Finland (UEF proj. 14907) and the Finnish Meteorological Institute (FMI proj. 260785), and is jointly funded by the Academy of Finland, UEF, and FMI. Support was also received from the Strategic Research Council at the Academy of Finland through the FORBIO (Sustainable, climate-neutral, and resource-efficient forest-based bioeconomy) project. We acknowledge the World Climate Research Programme's Working Group on Coupled Modelling, which is responsible for CMIP, and we thank the climate modelling groups (listed in Table 1 of this paper) for producing their model output and making it available. For CMIP, the US Department of Energy's Program for Climate Model Diagnosis and Intercomparison provided coordinating support and led the development of software infrastructure in partnership with the Global Organization for Earth System Science Portals. The ERA Interim data were downloaded from the European Centre for Medium-Range Weather Forecasts' data server. Kimmo Ruosteenoja is thanked for downloading and preprocessing the model data. We appreciate the help of Pentti Pirinen in interpolating the observational data onto the Finnish grid. Olle Räty and Jouni Räisänen from the Department of Physics, University of Helsinki, are acknowledged for developing the applied bias correction software. Finally, we are grateful to Mário Pereira and one anonymous referee for their assistance in improving the paper.

Edited by: R. Trigo

Reviewed by: M. G. Pereira and one anonymous referee

\section{References}

Aalto, J., Pirinen, P., Heikkinen, J., and Venäläinen, A.: Spatial interpolation of monthly climate data for Finland: comparing the performance of kriging and generalized additive models, Theor. Appl. Climatol., 112, 99-111, 2013.

Amatulli, G., Camia, A., and San-Miguel-Ayanz, J.: Estimating future burned areas under changing climate in the EUMediterranean countries, Sci. Total Environ., 450-451, 209-222, 2013.

Balshi, M. S., McGuire, A. D., Duffy, P., Flannigan, M., Walsh, J., and Melillo, J.: Assessing the response of area burned to changing climate in western boreal North America using a multivariate adaptive regression splines (MARS) approach, Global Change Biol., 15, 578-600, 2009.

Cattiaux, J., Douville, H., and Peings, Y.: European temperatures in CMIP5: origins of present-day biases and future uncertainties, Clim. Dynam., 41, 2889-2907, 2013.

Collins, W. J., Bellouin, N., Doutriaux-Boucher, M., Gedney, N., Halloran, P., Hinton, T., Hughes, J., Jones, C. D., Joshi, M., Liddicoat, S., Martin, G., O'Connor, F., Rae, J., Senior, C., Sitch, S., Totterdell, I., Wiltshire, A., and Woodward, S.: Development and evaluation of an Earth-System model - HadGEM2, Geosci. Model Dev., 4, 1051-1075, doi:10.5194/gmd-4-10512011, 2011.

Dai, A.: Increasing drought under global warming in observations and models, Nat. Clim. Change, 3, 52-58, 2013.

Dee, D. P., Uppala, S. M., Simmons, A. J., Berrisford, P., Poli, P., Kobayashi, S., Andrae, U., Balmaseda, M. A., Balsamo, G., Bauer, P., Bechtold, P., Beljaars, A. C. M., van de Berg, L., Bidlot, J., Bormann, N., Delsol, C., Dragani, R., Fuentes, M., Geer, A. J., Haimberger, L., Healy, S. B., Hersbach, H., Hólm, E. V., Isaksen, L., Kållberg, P., Köhler, M., Matricardi, M., McNally, A. P., Monge-Sanz, B. M., Morcrette, J.-J., Park, B.K., Peubey, C., de Rosnay, P., Tavolato, C., Thépaut, J.-N., and Vitart, F.: The ERA-Interim reanalysis: configuration and performance of the data assimilation system, Q. J. Roy. Meteorol. Soc., 137, 553-597, 2011.

de Groot, W. J., Goldhammer, J. G., Keenan, T., Brady, M. A., Lynham, T. J., Justice, C. O., Csiszar, I. A., and O'Loughlin, K.: Developing a global early warning system for wildland fire, in: Proceedings of the V International Conference on Forest Fire Research, 27-30 November 2006, Coimbra, edited by: Viegas, D. X., Elsevier, Amsterdam, 12 pp., 2006.

Donner, L. J., Wyman, B. L., Hemler, R. S., Horowitz, L. W., Ming, Y., Zhao, M., Golaz, J.-C., Ginoux, P., Lin, S.-J., Schwarzkopf, M. D., Austin, J., Alaka, G., Cooke, W. F., Delworth, T. L., Freidenreich, S. M., Gordon, C. T., Griffies, S. M., Held, I. M., Hurlin, W. J., Klein, S. A., Knutson, T. R., Langenhorst, A. R., Lee, H.-C., Lin, Y., Magi, B. I., Malyshev, S. L., Milly, P. C. D., Naik, V., Nath, M. J., Pincus, R., Ploshay, J. J., Ramaswamy, V., Seman, C. J., Shevliakova, E., Sirutis, J. J., Stern, W. F., Stouffer, R. J., Wilson, R. J., Winton, M., Wittenberg, A. T., and Zeng, F.: The dynamical core, physical parameterizations, and basic simulation characteristics of the atmospheric component AM3 of the GFDL global coupled model CM3, J. Climate, 24, 3484-3519, 2011.

Dowdy, A. J., Mills, G. A., Finkele, K., and de Groot, W.: Index sensitivity analysis applied to the Canadian forest fire weather index 
and the McArthur forest fire danger index, Meteorol. Appl., 17, 298-312, 2010.

Dury, M., Hambuckers, A., Warnant, P., Henrot, A., Favre, E., Ouberdous, M., and François, L.: Responses of European forest ecosystems to 21 st century climate: assessing changes in interannual variability and fire intensity, iForest, 4, 82-99, 2011.

Flannigan, M., Logan, K. A., Amiro, B. D., and Skinner, W. J.: Future area burned in Canada, Clim. Change, 72, 1-16, 2005.

Flannigan, M., Stocks, B., Turetsky, M., and Wotton, M.: Impacts of climate change on fire activity and fire management in the circumboreal forest, Global Change Biol., 15, 549-560, 2009.

Giorgi, F. and Coppola, E.: Projections of twenty-first century climate over Europe, Eur. Phys. J. Conf., 1, 29-46, 2009.

Granström, A.: Fire management for biodiversity in the European boreal forest, Scand. J. Forest Res., 16, 62-69, 2001.

Gregow, H., Ruosteenoja, K., Pimenoff, N., and Jylhä, K.: Changes in mean and extreme geostrophic wind speeds in northern Europe until 2100 based on nine global climate models, Int. J. Climatol., 32, 1834-1846, 2012.

Hawkins, E. and Sutton, R.: The potential to narrow uncertainty in regional climate predictions, B. Am. Meteorol. Soc., 90, 10951107, 2009.

Kellomäki, S., Peltola, H., Nuutinen, T., Korhonen, K. T., and Strandman, H.: Sensitivity of managed boreal forests in Finland to climate change, with implications for adaptive management, Philos. T. Roy. Soc. B, 363, 2341-2351, 2008.

Kilpeläinen, A., Kellomäki, S., Strandman, H., and Venäläinen, A.: Climate change impacts on forest fire potential in boreal conditions in Finland, Clim. Change, 103, 383-398, 2010.

Kilpeläinen, A., Torssonen, P., Strandman, H., Kellomäki, S., Asikainen, A., and Peltola, H.: Net climate impacts of forest biomass production and utilization in managed boreal forests, Global Change Biol. Bioenergy, doi:10.1111/gcbb.12243, online first, 2015.

Kuuluvainen, T.: Disturbance dynamics in boreal forests: defining the ecological basis of restoration and management of biodiversity, Silva Fenn., 36, 5-11, 2002.

Larjavaara, M., Kuuluvainen, T., and Rita, H.: Spatial distribution of lightning-ignited forest fires in Finland, Forest Ecol. Manage., 208, 177-188, 2005.

Lehtonen, I., Ruosteenoja, K., and Jylhä, K.: Projected changes in European extreme precipitation indices on the basis of global and regional climate model ensembles, Int. J. Climatol., 34, 12081222, 2014a.

Lehtonen, I., Ruosteenoja, K., Venäläinen, A., and Gregow, H.: The projected 21 st century forest-fire risk in Finland under different greenhouse gas scenarios, Boreal Environ. Res., 19, 127-139, 2014b.

Mäkelä, A., Enno, S.-V., and Haapalainen, J.: Nordic lightning information system: thunderstorm climate of Northern Europe for the period 2002-2011, Atmos. Res., 139, 46-61, 2014.

Mäkelä, H. M., Laapas, M., and Venäläinen, A.: Long-term temporal changes in the occurrence of a high forest fire danger in Finland, Nat. Hazards Earth Syst. Sci., 12, 2591-2601, doi:10.5194/nhess-12-2591-2012, 2012.

Mäkelä, H. M., Venäläinen, A., Jylhä, K., Lehtonen, I., and Gregow, H.: Probabilistic projections of climatological forest fire danger in Finland, Clim. Res., 60, 73-85, 2014.
Maraun, D.: Bias correction, quantile mapping, and downscaling: revisiting the inflation issues, J. Climate, 26, 2137-2143, 2013.

Migliavacca, M., Dosio, A., Camia, A., Hobourg, R., HoustonDurrant, T., Kaiser, J. W., Khabarov, N., Krasovskii, A. A., Marcolla, B., San Miguel-Ayanz, J., Ward, D. S., and Cescatti, A.: Modeling biomass burning and related carbon emissions during the 21 st century in Europe, J. Geophys. Res.-Biogeo., 118, 17321747, 2013.

Nakićenović, N., Joseph, A., Gerald, D., de Vries, B., Fenhann, J., Graffin, S., Gregory, K., Grubler, A., Jung, T. J., Kram, T., La Rovere, E. L., Michaelis, L., Mori, S., Morita, T., Pepper, W., Pitcher, H. M., Price, L., Riahi, K., Roehrl, A., Rogner, H.H., Sankovski, A., Schlesinger, M., Shukla, P., Smith, S. J., Swart, R., van Rooijen, S., Victor, N., and Dadi, Z.: Special Report on Emission Scenarios, A Special Report of Working Group III of the Intergovernmental Panel on Climate Change, Cambridge University Press, Cambridge, 2000.

Olsson, F., Gaillard, M.-J., Lemdahl, G., Greisman, A., Lanos, P., Marguerie, D., Marcoux, N., Skoglund, P., and Wäglind, J.: A continuous record of fire covering the last 10,500 calendar years from southern Sweden - The role of climate and human activities, Palaeogeogr. Palaeocl., 291, 128-141, 2010.

Osara, N. A.: Kulovalkeat, in: Suuri Metsäkirja, 1 osa, edited by: Kaleva, E. K., Werner Söderström osakeyhtiö, Porvoo, 455-486, 1949.

Pereira, M. G., Calado, T. J., DaCamara, C. C., and Calheiros, T.: Effects of regional climate change on rural fires in Portugal, Clim. Res., 57, 187-200, 2013.

Power, M. J., Marlon, J., Ortiz, N., Bartlein, P. J., Harrison, S. P., Mayle, F. E., Ballouche, A., Bradshaw, R. H. W., Carcaillet, C., Cordova, C., Mooney, S., Moreno, P. J., Prentice, I. C., Thonicke, K., Tinner, W., Whitlock, C., Zhang, Y., Zhao, Y., Ali, A. A., Anderson, R. S., Beer, R., Behling, H., Briles, C., Brown, K. J., Brunelle, A., Bush, M., Camill, P., Chu, G. Q., Clark, J., Colombaroli, D., Connor, S., Daniau, A.-L., Daniels, M., Dodson, J., Doughty, E., Edwards, M. E., Finsinger, W., Foster, D., Frechette, J., Gaillard, M. J., Gavin, D. G., Gobert, E., Haberle, S., Hallett, D. J., Higuera, P., Hope, G., Horn, S., Inoue, J., Kaltenrieder, P., Kennedy, L., Kong, Z. C., Larsen, C., Long, C. J., Lynch, J., Lynch, E. A., McGlone, M., Meeks, S., Mensing, S., Meyer, G., Minckley, T., Mohr, J., Nelson, D. M., New, J., Newnham, R., Noti, R., Oswald, W., Pierce, J., Richard, P. J. H., Rowe, C., Sanchez Goñi, M. F., Shuman, B. N., Takahara, H., Toney, J., Turney, C., UrregoSanchez, D. H., Umbanhowar, C., Vandergoes, M., Vanniere, B., Vescovi, E., Walsh, M., Wang, X., Williams, N., Wilmshurst, J., and Zhang, J. H.: Changes in fire regimes since the Last Glacial Maximum: an assessment based on a global synthesis and analysis of charcoal data, Clim. Dynam., 30, 887-907, 2008.

Räisänen, J. and Eklund, J.: 21st century changes in snow climate in northern Europe: a high-resolution view from ENSEMBLES regional climate models, Clim. Dynam., 38, 2575-2591, 2012.

Räisänen, J. and Räty, O.: Projections of daily mean temperature variability in the future: cross-validation tests with ENSEMBLES regional climate simulations, Clim. Dynam., 41, 15531568, 2013.

Räisänen, J. and Ylhäisi, J. S.: $\mathrm{CO}_{2}$-induced climate change in northern Europe: CMIP2 versus CMIP3 versus CMIP5, Clim. Dynam., 45, 1877-1897, 2015. 
Räty, O., Räisänen, J., and Ylhäisi, J. S.: Evaluation of delta change and bias correction methods for future daily precipitation: intermodel cross-validation using ENSEMBLES simulations, Clim. Dynam., 42, 2287-2303, 2014.

Reinikainen, A., Mäkipää, R., Vanha-Majamaa, I., and Hotanen, J.P. (Eds): Kasvit muuttuvassa metsäluonnossa, Tammi, Helsinki, 2000.

Ruosteenoja, K. and Räisänen, P.: Seasonal changes in solar radiation and relative humidity in Europe in response to global warming, J. Climate, 26, 2467-2481, 2013.

Ruosteenoja, K., Räisänen, J., and Pirinen, P.: Projected changes in thermal seasons and the growing season in Finland, Int. J. Climatol., 31, 1473-1487, 2011.

Saari, E.: Kuloista etupäässä Suomen valtionmetsiä silmällä pitäen, Acta Forestalia Fenn., 26, 1-142, 1923.

Sherstyukov, B. G. and Sherstyukov, A. B.: Assessment of increase in forest fire risk in Russia till the late 21st century based on scenario experiments with fifth-generation climate models, Russ. Meteorol. Hydrol., 39, 292-301, 2014.

Stocks, B. J., Mason, J. A., Todd, J. B., Bosch, E. M., Wotton, B. M., Amiro, B. D., Flannigan, M. D., Hirsch, K. G., Logan, K. A., Martell, D. L., and Skinner, W. R.: Large forest fires in Canada, 1959-1997, J. Geophys. Res., 108, D8149, doi:10.1029/2001JD000484, 2002.

Tanskanen, H. and Venäläinen, A.: The relationship between fire activity and fire weather indices at different stages of the growing season in Finland, Boreal Environ. Res., 13, 285-302, 2008.

Taylor, K. E., Stouffer, R. J., and Meehl, G. A.: An overview of CMIP5 and the experimental design, B. Am. Meteorol. Soc., 93, 485-498, 2012.

Teutschbein, C. and Seibert, J.: Bias correction of regional climate model simulations for hydrological climate-change impact studies: review and evaluation of different methods, J. Hydrol., 456457, 12-29, 2012.

Vajda, A., Venäläinen, A., Suomi, I., Junila, P., and Mäkelä, H. M.: Assessment of forest fire danger in a boreal forest environment: description and evaluation of the operational system applied in Finland, Meteorol. Appl., 21, 879-887, 2014.

van Vuuren, D. P., Edmonds, J., Kainuma, M., Riahi, K., Thomson, A., Hibbard, K., Hurtt, G. C., Kram, T., Krey, V., Lamarque, J.F., Masui, T., Meinshausen, M., Nakicenovic, N., Smith, S. J., and Rose, S. K.: The representative concentration pathways: an overview, Clim. Change, 109, 5-31, 2011.
Van Wagner, C. E.: Development and structure of the Canadian Forest Fire Weather Index System, Forestry Technical Report 35, Canadian Forestry Service, Ottawa, ON, 1987

Van Wagner, C. E. and Pickett, T. L.: Equations and FORTRAN Program For the Canadian Forest Fire Weather Index System, Forestry Technical Report 33, Canadian Forestry Service, Ottawa, ON, 1985.

Venäläinen, A., Korhonen, N., Hyvärinen, O., Koutsias, N., Xystrakis, F., Urbieta, I. R., and Moreno, J. M.: Temporal variations and change in forest fire danger in Europe for 1960-2012, Nat. Hazards Earth Syst. Sci., 14, 1477-1490, doi:10.5194/nhess-141477-2014, 2014.

Voldoire, A., Sanchez-Gomez, E., Salas y Mélia, D., Decharme, B., Cassou, C., Sénési, S., Valcke, S., Beau, I., Alias, A., Chevallier, M., Déqué, M., Deshayes, J., Douville, H., Fernandez, E. Madec, G., Maisonnave, E., Moine, M.-P., Planton, S., SaintMartin, D., Szopa, S., Tyteca, S., Alkama, R., Belamari, S., Braun, A., Coquart, L., and Chauvin, F.: The CNRM-CM5.1 global climate model: description and basic evaluation, Clim. Dynam., 40, 2091-2121, 2013.

von Salzen, K., Scinocca, J. F., McFarlane, N. A., Li, J., Cole, J. N. S., Plummer, D., Verseghy, D., Reader, M. C., Ma, X., Lazare, M., and Solheim, L.: The Canadian fourth generation atmospheric global climate model (CanAM4) - Part I: representation of physical processes, Atmos. Ocean, 51, 104-125, 2013.

Wallenius, T.: Major decline in fires in coniferous forests - reconstructing the phenomenon and seeking for the cause, Silva Fenn., 45, 139-155, 2011.

Watanabe, M., Suzuki, T., O'ishi, R., Komuro, Y., Watanabe, S., Emori, S., Takemura, T., Chikira, M., Ogura, T., Sekiguchi, M., Takata, K., Yamazaki, D., Yokohata, T., Nozawa, T., Hasumi, H., Tatebe, H., and Kimoto, M.: Improved climate simulation by MIROC5: mean states, variability, and climate sensitivity, J. Climate, 23, 6312-6335, 2010.

Wilcke, R. A. I., Mendlik, T., and Gobiet, A.: Multi-variable error correction of regional climate models, Clim. Change, 120, 871887, 2013.

Xiao, J. and Zhuang, Q.: Drought effects on large fire activity in Canadian and Alaskan forests, Environ. Res. Lett., 2, 044003, doi:10.1088/1748-9326/2/4/044003, 2007.

Yang, W., Gardelin, M., Olsson, J., and Bosshard, T.: Multi-variable bias correction: application of forest fire risk in present and future climate in Sweden, Nat. Hazards Earth Syst. Sci., 15, 2037-2057, doi:10.5194/nhess-15-2037-2015, 2015. 